\title{
Raw coffee processing yield affected more by cultivar than by harvest date ${ }^{1,2}$
}

\author{
Teodoro Espinosa-Solares, ${ }^{3}$ Juan Guillermo Cruz-Castillo, ${ }^{4}$ \\ Osval Antonio Montesinos-López ${ }^{3}$ and Arturo Hernández-Montes ${ }^{3}$
}

J. Agric. Univ. P.R. 89(3-4):169-180 (2005)

\begin{abstract}
Conversion of cherry and parchment coffee (Coffea arabica L.) to green coffee was determined during two consecutive years of harvest for eight different coffee cultivars grown in Mexico. 'Mass balance' was useful to adjust the fruit humidity to $0.12 \mathrm{~g} / \mathrm{g}$ for coffee bean raw processing. Univariate and multivariate analyses showed significant differences $(P \leq 0.05)$ among the cultivars. A linear discriminant function based on twelve variables measured on several dates in two consecutive harvest years showed that 'Typica' and 'Mundo Novo' had high efficiencies in conversions from cherry to green coffee on three harvest dates in 1999 and one in 2000. In contrast, 'Bourbon' and 'Yellow Caturra' required greater amount of fresh fruit to obtain $46 \mathrm{~kg}$ (1 quintal) of green coffee. The cultivar effects on the parchment to green coffee bean yield were not clearly identified. Harvest dates studied did not significantly influence the conversion of cherry or parchment to green coffee bean yields in the two years evaluated.
\end{abstract}

Key words: Coffea arabica, coffee beans, raw coffee processing, parchment coffee, green coffee

\section{RESUMEN}

Influencia del cultivar y de la fecha de cosecha en el beneficiado industrial de granos de café

Se estudiaron conversiones de café cereza y café pergamino a granos de café verde o pilado (Coffea arabica L.) en ocho cultivares de cafeto, durante dos años consecutivos de cosecha en México. Un 'balance de masas' fue útil en ajustar la humedad del fruto a $0.12 \mathrm{~g} / \mathrm{g}$ para granos de café a procesar. Análisis univariados y multivariados mostraron diferencias significativas $(P \leq 0.05)$ entre los cultivares. Una función lineal discriminante basada

\section{${ }^{1}$ Manuscript submitted to Editorial Board 9 March 2005.}

${ }^{2}$ The authors thank the Universidad Autónoma Chapingo for funding this study. M.C. Esteban Escamilla, Ing. Francisco López, Ing. Amilkar López, Ing. Lauro Rayón and Ing. Rutilo Enriquez are thanked for their help on the coffee plantation and for supplying technical information. Also Dr. Bruce R. MacKay, from the Institute of Food Nutrition and Human Health (Massey University, New Zealand), and Dr. Carlos Guadarrama-Zugasti from the Center for the Development of Coffee Regions (Universidad Autónoma Chapingo, México) are thanked for their manuscript comments.

${ }^{3}$ Departamento de Ingeniería Agroindustrial. Universidad Autónoma Chapingo. P.O. Box 161, Chapingo, 56230, Edo. de México, México. E-mail: espinosa@chapingo.mx

${ }^{4}$ Centro Regional Universitario Oriente. Universidad Autónoma Chapingo. P.O. Box 49, Huatusco, Veracruz, México. 94100. E-mail: jcruzcastillo@yahoo.com 


\begin{abstract}
en doce variables medidas en varias fechas durante dos años consecutivos de cosecha mostró que 'Typica' y 'Mundo Novo' tuvieron una alta eficiencia en conversiones de café cereza a granos de café verde en tres épocas de cosecha en 1999 y una en el 2000. En contraste, 'Bourbon' y 'Caturra AmariIlo' requirieron una mayor cantidad de fruto fresco o café cereza para obtener $46 \mathrm{~kg}(1 \mathrm{Qq})$ de granos de café verde. La influencia de los cultivares en el rendimiento industrial de café pergamino a granos de café verde no se identificó claramente. Las fechas de corte estudiadas no influyeron significativamente en la conversión de café cereza o café pergamino a granos de café verde en dos años de estudio.
\end{abstract}

Palabras clave: Coffea arabica, granos de café, procesamiento industrial de café, café pergamino, café verde, café pilado

\title{
INTRODUCTION
}

Coffee is the most important tropical crop consumed worldwide. According to van der Stegen (2003), the world production of coffee amounts to $\sim 110$ million $60-\mathrm{kg}$ bags per year (6.6 million tons/year), with about 90 million bags in the exportation market. The adequate moisture content for storage of green coffee beans is near $0.12 \mathrm{~g} / \mathrm{g}$ (Atmawinata, 1995); consequently, the reference for trade operations is based on this moisture value. The international coffee market recognizes factors that influence coffee quality: species, plantation altitude, latitude, cultivars, raw coffee processing type, physical quality of green coffee and sensory properties of coffee beverage (Villa, 1990; PuertaQuintero, 2000a; Figueroa-Solares et al., 2000; Njoroge, 1998; Reyna, 1989; González-Arcos, 1996). Coffee beverages are made from roasted green coffee beans of two species with economic importance, Coffea arabica and C. canephora (P.), known in the trade market as arabica and robusta, respectively (Martín et al., 2001). Coffea arabica presents high standards in aroma and flavor whereas C. canephora contains higher caffeine and soluble solid levels (Cléves-Serrano, 1998; Ky et al., 2001).

The transformation from coffee fruit cherries to green coffee beans, known as raw coffee processing, plays an important role in the final quality of the beverage. In fact, coffee quality is obtained in the field and it is preserved during raw coffee processing. Wet and dry processes are the two main methods used for green coffee production. Wet processing differs from dry processing basically in the production of parchment coffee as an intermediate product, whereas dry processing has dried cherries as an in-between product (Figure 1). Previous to trade, parchment coffee can be stored for almost one year without any loss because of the isolation provided by the endocarp. Mexican green coffee beans are mainly obtained from $C$. arabica and produced by wet processing. The beverages produced through this process have a high acidity and distinctive aroma.

Fruit yield, tolerance to pathogens, and environmental adaptation have been key criteria for coffee breeding (Villaseñor, 1987). However, 


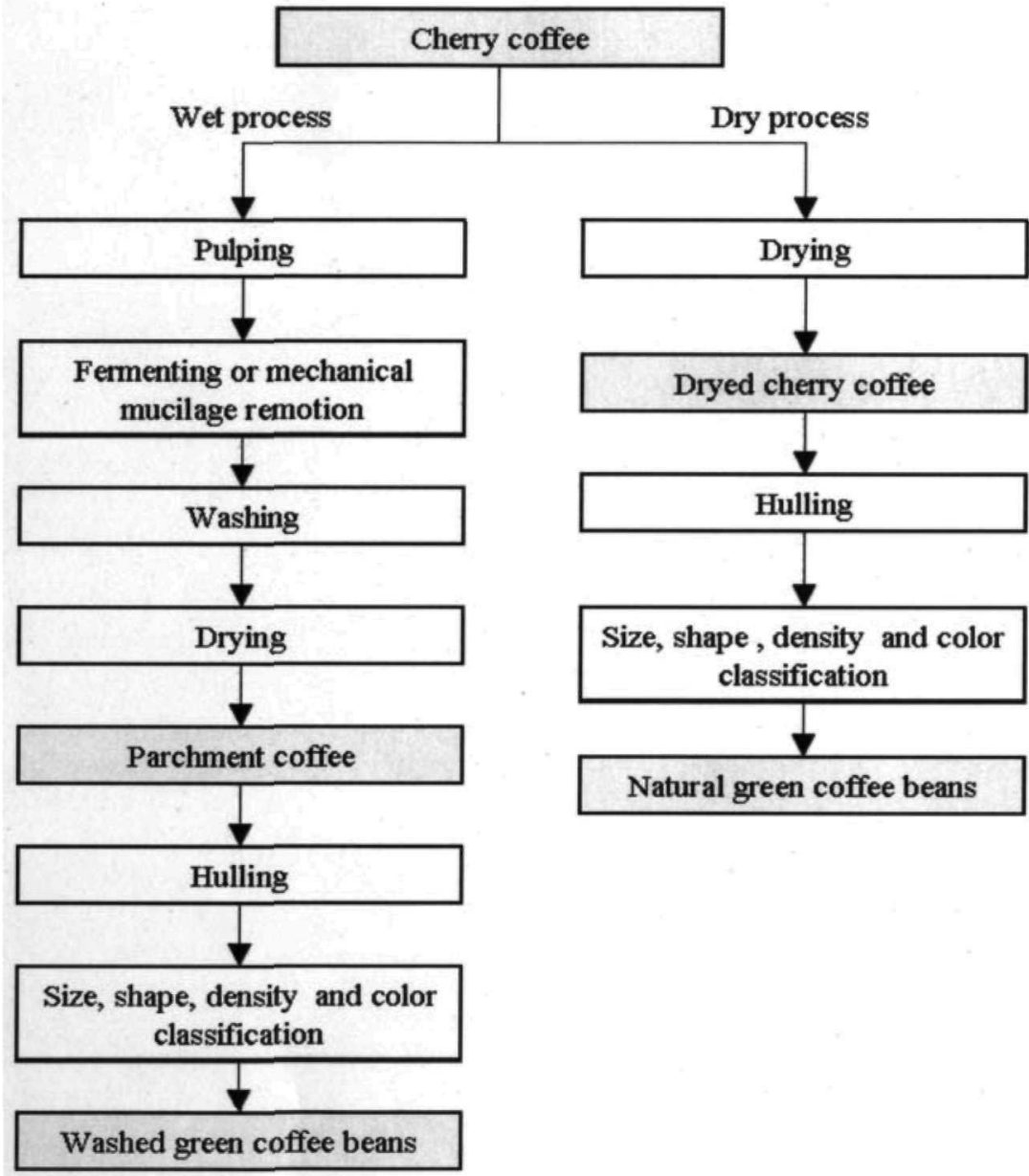

FIGURE 1 . Wet and dry cherry coffee processing.

since green coffee is the final product, it is important to consider wet processing yields in breeding programs. Specifically, it is valuable to study the conversion from cherry to parchment and from parchment to green coffee beans. In commercial coffee trade agreements, $57.5 \mathrm{~kg}$ of parchment coffee is considered as one 'Quintal' (Qq), which corresponds to 46 $\mathrm{kg}$ of green coffee at $0.12 \mathrm{~g} / \mathrm{g}$ of humidity. Some authors have demonstrated that raw coffee processing yield is affected by cultivar, plant age, location and fruit ripeness grade (Castillo, 1981; Guyot et al., 1996; Montagnon et al., 2000; Soto-Pinto et al., 2000). Coffee growers assume that 
processing yield increases as harvest date advances. In Africa, there is information on this assumption (Haarer, 1980). However, the influence of harvest date on raw coffee processing has not been carefully studied in Mexico. In fact, there are only a few local reports concerning this issue.

Puerta-Quintero (2000b) reported the negative influence of immature beans on wet processing. Parchment coffee yield of immature beans was reduced by $7 \%$ as compared to that of ripe beans. This author also showed that immature beans affect physical and sensory properties; thus, the higher percentage of ripe coffee in a sample, the higher number of good quality cups is obtained.

Reyna (1989) found that cultivar influenced processing yield. In that study, 'Typica' required $230.4 \mathrm{~kg}$ of ripe cherry fruit to produce $1 \mathrm{Qq}$ of green coffee, followed by 'Villa Sarchî' (241.5 kg), 'Catuaî' (246.5 kg), 'Pacas' (250.2 kg), and 'Caturra' (256.2 kg). Guadarrama and Trujillo (2001) showed that the conversion from cherry to parchment in 'Mundo Novo' was influenced by the environmental conditions of the plantation.

The present work was conducted to determine the influence of harvest dates on green coffee yields for several coffee cultivars in a Mexican tropical upland environment producing high quality green coffee beans. Mass balance, univariate and multivariate analysis of variance, and canonical discriminant analysis were used to evaluate conversion changes from cherry to green coffee and parchment to green coffee obtained by wet processing in two consecutive years of harvest.

\section{MATERIALS AND METHODS}

Plantation and harvest. An 18-year-old coffee (C. arabica) plantation established on an Andosol soil, located at 1,344 $\mathrm{m}$ above sea level at the Centro Regional Universitario Oriente of the Universidad Autónoma Chapingo in Huatusco, Veracruz, Mexico ( $19^{\circ} 09^{\prime} \mathrm{N}$ and $96^{\circ} 57^{\prime}$ W), was used in the experiment. The study area had a mean annual rainfall of $1,700 \mathrm{~mm}$, and an annual temperature average of $17.2^{\circ} \mathrm{C}$. Eight cultivars widely grown on local plantations were selected: Garnica, Typica, Pluma Hidalgo, Catuaí, Red Caturra, Yellow Caturra, Mundo Novo, and Bourbon. According to the classification of type of canopy (Gobbi, 2000), the production system had a 'technified' shade, with predominancy of Inga sp. trees. Fruit harvested in 1999 and 2000 was considered in the study. Three hand harvests were performed each year. The first two harvests were in January and February in both years, and the last in March of 1999, and May of 2000. The criterion adopted in defining the harvest date was the red color of the fruit skin as indicator of ripening. Yellow Caturra was harvested when the fruit attained a yellow color. 
Raw coffee processing. Three replicates of $2-\mathrm{kg}$ samples of cherry coffee were randomly harvested and processed by the wet method for each cultivar and harvest date. Only ripe fruits were used throughout all the experiments. The fruit processing included pulping, fermenting, washing, and drying. The product obtained was parchment coffee at a humidity of about $0.12 \mathrm{~g} / \mathrm{g}$. Afterwards, parchment was hulled to obtain green coffee beans.

Mass balance and conversion factors. Mass balances were used to standardize the samples to $0.12 \mathrm{~g} / \mathrm{g}$ of humidity (Himmelblau, 1997). Cherry to green coffee $\left(\mathrm{CF}_{\mathrm{Ch}-\mathrm{G}}\right)$ and parchment to green coffee $\left(\mathrm{CF}_{\mathrm{P}-\mathrm{G}}\right)$ conversion factors were used for comparing the raw coffee processing yield. Both conversion factors were defined by using the mass of the samples of each treatment and defined by equations 1 and 2. These equations define, respectively, the amount of cherry and parchment needed to obtain $46 \mathrm{~kg}$ ( $1 \mathrm{Qq})$ of green coffee beans.

$$
\begin{aligned}
& C F_{C h-\mathrm{G}}=\frac{\frac{46 \mathrm{~kg}}{\text { mass of green coffee }}}{\text { mass of cherry }} \\
& C F_{P-G}=\frac{\frac{46 \mathrm{~kg}}{\text { mass of green coffee }}}{\text { mass of parchment }}
\end{aligned}
$$

Statistical analysis. Univariate (Steel and Torrie, 1980) and multivariate analysis of variance (Krzanowski, 1988) and canonical discriminant analysis (Cruz-Castillo et al., 1994) were performed to compare the influence of harvest date and cultivar on raw coffee processing yield, considering the cherry to green coffee and parchment to green coffee conversion factors over two-year harvests. The SAS (1989) ANOVA and CANDISC procedures were used to perform these statistical techniques.

\section{RESULTS AND DISCUSSION}

Mass balance was useful in obtaining the equivalent amount of parchment and green coffee beans at the typical commercial humidity $(0.12 \mathrm{~g} / \mathrm{g})$. Cherry to green coffee yields were significantly $(\mathrm{P} \leq 0.05)$ affected by the cultivars on most of the different harvest dates (Table 1). The Typica cultivar achieved the highest cherry to green coffee conversion, to complete $45.45 \mathrm{~kg}$ of green coffee (1 Qq) in March 1999 and in May 2000 with 241.9 and $231.3 \mathrm{~kg}$, respectively. Coffee growers in Huatusco, Mexico, claim that the best yield conversions from cherry to 
TABLE 1.-Harvest dates in January (J), February $(F)$, March $(M)$, May (My) and factor conversion means $(\mathrm{kg})$ of cherry to green $\left(C F_{C h-G}\right)$ and parchment to green coffee ( $\left.C F_{P-G}\right)$ for eight different coffee cultivars in the harvest seasons of 1999 and 2000.

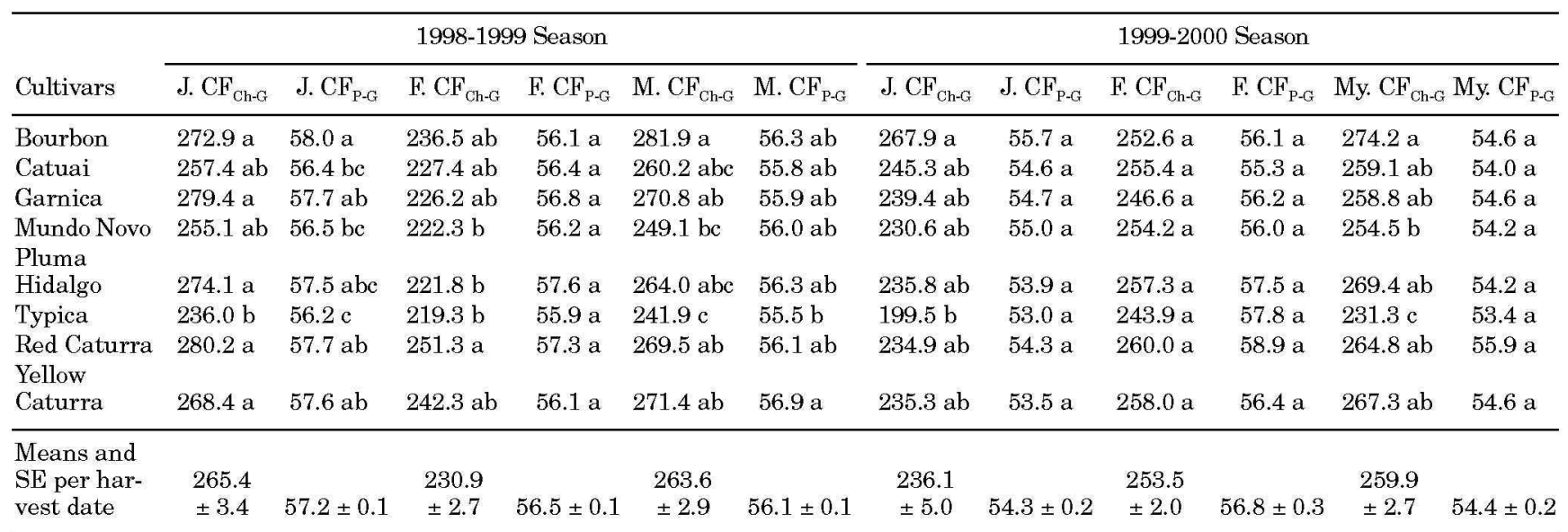

\footnotetext{
Mean separation in each column by Tukey at $5 \%$.
} 
green coffee occurred at the end of the harvest period. In the present work, there was not any late high harvest industrial yield trend when all cultivars were considered. For example, the first harvest in January 2000 achieved a high cherry to green coffee yield conversion across all the cultivars ( $236.1 \mathrm{~kg}$ ). Likewise, this conversion was high in February during the first harvest season $(230.9 \mathrm{~kg}$ ). Particular cultivar effects influenced by harvest date in this regard were shown by Bourbon, Catuaí, Mundo Novo, Typica, and Yellow Caturra with high cherry to green conversions in January for each season (Table 1). In contrast, Red Caturra, Pluma Hidalgo, and Garnica did not follow any harvest trend in the cherry to green coffee conversion in either season (Table 1). Thus, pre-harvest factors such as management of the plantation shade (Muschler, 2000) may be more important in some cultivars for achieving adequate yield conversion values irrespective of the time of harvest. In a study in Costa Rica, cultivars with longer periods of fruit growth on the plant produce the heaviest green coffee beans (Alpizar, 2000), but there are no similar reports for Mexico. Typica was significantly different from the other cultivars in May 2000, achieving $231.2 \mathrm{~kg}$ of cherry for $46 \mathrm{~kg}$ of green coffee (Table 1). The parchment to green yield conversion in the first season was significantly different among the cultivars in January and March for Catuaí, Mundo Novo, Pluma Hidalgo, and Typica, requiring less parchment coffee to attain $46 \mathrm{~kg}$ of green coffee (Table 1). In the second season, all cultivars had similar parchment to green coffee conversions (Table $\mathbf{1}$ ).

The multivariate analysis of variance showed significant differences $(P \leq 0.05)$ among the eight different cultivars, where cherry to green and parchment to green coffee yield conversion factors were measured on different harvest dates, in two consecutive harvest seasons. The canonical discriminant analysis showed that the first two canonical functions were significantly different $(P \leq 0.05)$ from the other four canonical functions, thus indicating that the eight different cultivars differed most in these two linear functions, which accounted for $91.2 \%$ of the variation (Table 2 ). The first canonical discriminant $\left(\mathrm{CDF}_{1}\right)$ function explained $83.2 \%$ of the variability, and it was highly associated with the cherry to green coffee conversions in March 1999 and May 2000 , according to the correlation coefficients between the $\mathrm{CDF}_{1}$ and all the conversion values. The standardized canonical coefficients in the $\mathrm{CDF}_{1}$ showed large absolute values for the conversion of cherry to green coffee in May 2000, and January, February, and March 1999. Absolute values were also high for the parchment to green coffee conversions in May 2000 and February 1999. Typica, with the highest absolute score (Table 3), was distinctly different from the other cultivars. With Typica, less harvest yield was needed to obtain $46 \mathrm{~kg}$ of 
TABLE 2.-Standarized canonical coefficients (SCC) and correlation coefficients between canonical discriminant functions $\left(C D F_{1}, C D F_{2}\right)$, and factor conversions of cherry to green $\left(C F_{C h-G}\right)$, and parchment to green coffee $\left(C F_{P-G}\right)$ for eight different coffee cultivars in the harvest seasons of 1999 and 2000.

\begin{tabular}{|c|c|c|c|c|c|}
\hline \multirow[b]{2}{*}{ Variables } & \multirow{2}{*}{$\begin{array}{l}\text { Notation in } \\
\text { Equation } 3\end{array}$} & \multicolumn{2}{|c|}{$\mathrm{CDF}_{1}$} & \multicolumn{2}{|c|}{$\mathrm{CDF}_{2}$} \\
\hline & & $\mathrm{SCC}$ & $r^{2}$ & $\mathrm{SCC}$ & $\mathrm{r}^{2}$ \\
\hline \multicolumn{6}{|l|}{ 1998-1999 Season } \\
\hline January. $\mathrm{CF}_{\mathrm{Ch}-\mathrm{G}}$ & $\mathrm{X}_{1}$ & 1.29 & 0.63 & -0.35 & 0.07 \\
\hline January. $\mathrm{CF}_{P-G}$ & $\mathrm{X}_{2}$ & -0.36 & 0.64 & 0.89 & 0.14 \\
\hline February. $\mathrm{CF}_{\mathrm{Ch}-\mathrm{G}}$ & $\mathrm{X}_{3}$ & 3.55 & 0.50 & 0.17 & 0.15 \\
\hline February. $\mathrm{CF}_{\mathrm{P}-\mathrm{G}}$ & $\mathrm{X}_{4}$ & -2.39 & 0.11 & -0.60 & -0.21 \\
\hline Mareh. $\mathrm{CF}_{\mathrm{Ch}-\mathrm{G}}$ & $\mathrm{X}_{5}$ & 1.24 & 0.80 & 2.92 & 0.22 \\
\hline March. $\mathrm{CF}_{\mathrm{P}-\mathrm{G}}$ & $\mathrm{X}_{6}$ & -0.64 & 0.55 & -1.67 & -0.31 \\
\hline \multicolumn{6}{|l|}{ 1999-2000 Season } \\
\hline January. $\mathrm{CF}_{\mathrm{Ch}-\mathrm{G}}$ & $\mathrm{X}_{7}$ & 1.85 & 0.66 & 1.38 & 0.14 \\
\hline January. $\mathrm{CF}_{\mathrm{P}-G}$ & $\mathrm{X}_{8}$ & -0.48 & 0.38 & 0.81 & 0.30 \\
\hline February. $\mathrm{CF}_{\mathrm{Ch}-\mathrm{G}}$ & $\mathrm{X}_{9}$ & 0.52 & 0.33 & -0.41 & -0.30 \\
\hline February. $\mathrm{CF}_{\mathrm{P}-\mathrm{G}}$ & $\mathrm{X}_{10}$ & -0.09 & -0.15 & -0.30 & -0.01 \\
\hline May. $\mathrm{CF}_{\mathrm{Ch}-G}$ & $\mathrm{X}_{11}$ & 6.96 & 0.88 & -3.98 & -0.16 \\
\hline May. $\mathrm{CF}_{\mathrm{P}-\mathrm{G}}$ & $\mathrm{X}_{12}$ & -3.59 & 0.31 & 1.92 & 0.12 \\
\hline \multicolumn{2}{|c|}{ Variance explained (\%) } & 83.2 & & 8.0 & \\
\hline
\end{tabular}

green coffee in 1999 [219 kg (Feb); $236 \mathrm{~kg}$ (Jan); and 242 (Mar)]; and in 2000 [200 kg (Jan); $231 \mathrm{~kg}$ (May)] (Table 1). Reyna (1989) also demonstrated that Typica fruit was highly efficient at producing green coffee. Regarding parchment to green coffee conversion for Typica, the low correlation coefficient values (Table 2 ), and non significant $(\mathrm{P} \leq 0.05)$ mean values (Table 1) in February 1999 and May 2000 indicated no distinct

TABLE 3.-Means of standardized canonical scores of the first two canonical discriminant functions (CDFs) for eight different coffee cultivars in the harvest coffee seasons of 1999 and 2000.

\begin{tabular}{lcc}
\hline Coffee Cultivars & $\mathrm{CDF}_{1}$ & $\mathrm{CDF}_{2}$ \\
\hline Bourbon & $13.3 \mathrm{a}$ & $3.1 \mathrm{a}$ \\
Yellow Caturra & $7.8 \mathrm{~b}$ & $-2.7 \mathrm{ed}$ \\
Red Caturra & $2.7 \mathrm{c}$ & $1.4 \mathrm{ab}$ \\
Catuaí & $1.1 \mathrm{c}$ & $-0.1 \mathrm{bc}$ \\
Pluma Hidalgo & $0.7 \mathrm{ed}$ & $-4.8 \mathrm{~d}$ \\
Garnica & $-1.7 \mathrm{~d}$ & $3.5 \mathrm{a}$ \\
Mundo Novo & $-5.5 \mathrm{e}$ & $-1.6 \mathrm{c}$ \\
Typica & $-18.5 \mathrm{f}$ & $1.2 \mathrm{ab}$ \\
\hline
\end{tabular}

Mean separation in each column by Tukey at $5 \%$. 
advantages with respect to the other cultivars in completing $46 \mathrm{~kg}$ of green coffee. These findings could be attributed to the dependence of this conversion on the endosperm-endocarp ratio, which varies with the natural differences among fruits (Puerta-Quintero, $2000 \mathrm{~b}$ ). Although Mundo Novo was significantly different from Typica (Table 3), it also scored high in this linear function and showed efficiency in attaining 1 $\mathrm{Qq}$ on the above mentioned dates. Typica presented higher fruit weight and larger seeds but lower total yield on the coffee plantations in comparison with the other cultivars studied (Villaseñor, 1987). In addition to cultivar effects on coffee conversion ratios (Temesgen and Michael, 1995), cultural practices to increase coffee bean weight in other coffee cultivars may enhance cherry to green coffee conversion yields. For example, mulching (Kamau, 1976), optimal balance of nutrients (Njoroge, 1998) or shade (Muschler, 2000) may benefit coffee industrial yield conversions. In contrast, Bourbon and Yellow Caturra following with high absolute scores (Table 3 ) required more cherry fruit to completing $46 \mathrm{~kg}$ (1 Qq) of green coffee those dates (Table 1). As with Typica, no clear advantages were observed for these cultivars with respect to complete 46 $\mathrm{kg}$ (1 Qq) of green coffee from parchment (Table 1). The $\mathrm{CDF}_{2}$ accounted for only $8.0 \%$ of the variation among the coffee cultivars; therefore, this function was not used for interpretation.

A plot of the canonical coefficient scores (Figure 2) of the coffee cultivars illustrates the high discriminant capacity of $\mathrm{CDF}_{1}$ in separating Typica and Bourbon from the other cultivars, mainly on the basis of their cherry to green coffee conversions in January, February, March 1999, and May 2000. Thus on the basis of the linear combination presented in Equation 3, the complexity of the data was summarized. This model was useful to understand coffee conversion yields on several harvest dates carried out with eight different coffee cultivars.

$$
\begin{gathered}
\mathrm{CDF}_{1}=1.29 \mathrm{x}_{1}-0.36 \mathrm{x}_{2}+3.55 \mathrm{x}_{3}-2.39 \mathrm{x}_{4}+1.24 \mathrm{x}_{5}-0.64 \mathrm{x}_{6}+ \\
1.85 \mathrm{x}_{7}-0.48 \mathrm{x}_{8}+0.52 \mathrm{x}_{9}-0.09 \mathrm{x}_{10}+6.96 \mathrm{x}_{11}-3.59 \mathrm{x}_{12}
\end{gathered}
$$

Where $\mathrm{x}_{1}, \mathrm{x}_{2}, \ldots, \mathrm{x}_{12}$ represent the cherry and parchment to green coffee conversion factors described in Table 2.

In general, Bourbon and Yellow Caturra yield more fruit than Typica and Mundo Novo (Villaseñor, 1987). However, in the present work Typica showed higher cherry to green coffee conversions because the size of the beans was larger. Therefore, local cherry producer growers would receive premium prices from the coffee processor industry for Typica and Mundo Novo fruit because of the high conversion rate of cherry to green coffee, and less reward for cherries harvested from 


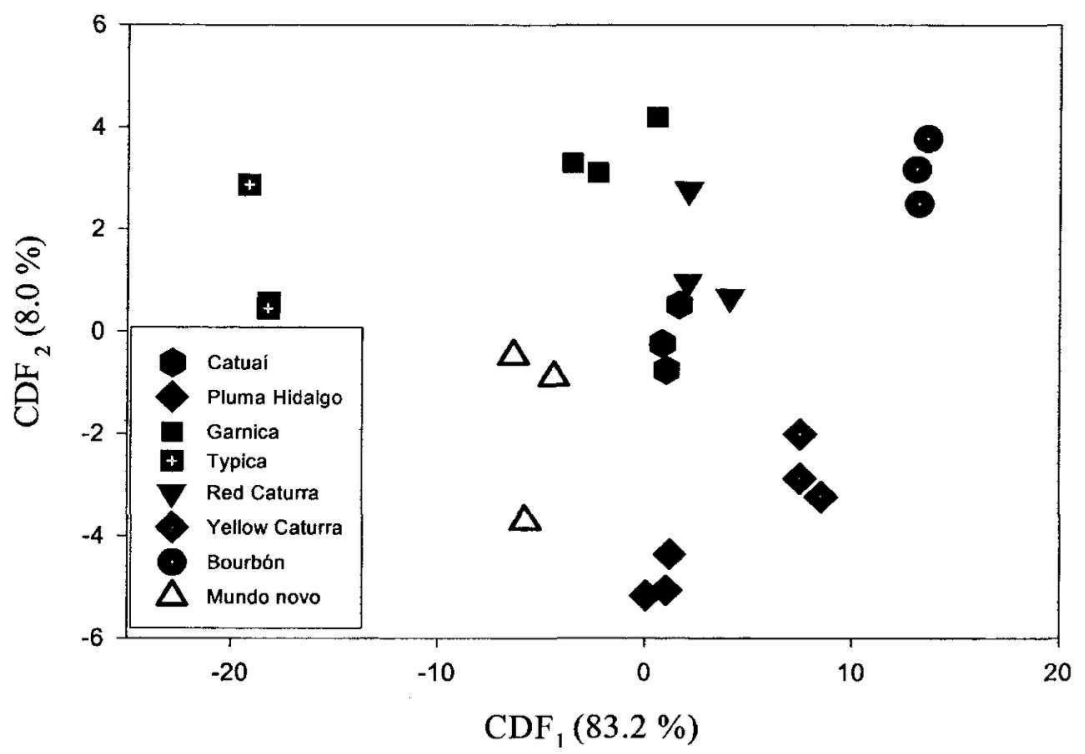

FIGURE 2. Plot of the canonical scores of the first two canonical discriminant functions for cherry to green, and parchment to green coffee conversions harvested on different dates in 1999 and 2000 for eight different coffee cultivars.

Bourbon and Yellow Caturra. The decision on planting cultivars will depend on the grower market strategy commercializing cherry, parchment or green coffee.

\section{LITERATURE CITED}

Alpizar, J. M., 2000. Comportamiento de los rendimientos de beneficiado de café de Costa Rica por zonas de producción, según registros de 15 años. pp. 467-471. In: L. Zamora and J. Echeverri (ed.), XIX Simposio Latinoamericano de Caficultura, Memoria, ICAFE, San José, Costa Rica.

Atmawinata, O., 1995. The safe storage moisture content for green coffee. Pelita Perkebunan 11:38-44.

Castillo, C. F., 1981. Evaluación de Catimor Brote Bronce y Caturra Criollo desde el crecimiento hasta la productividad. pp. 208-216. In: Simposium Latinoamericano sobre Caficultura, Guatemala.

Cléves-Serrano, R., 1998. Factores que inciden en la calidad del café, originados en el cultivo y la recolección. pp. 8-14. In: R. Cléves-Serrano (ed.), Tecnología en beneficiado de café, San José, Costa Rica.

Cruz-Castillo, J. G., S. Ganeshanandam, B. R. MacKay, G. S. Lawes, C. R. O. Lawoko and D. J. Woolley, 1994. Applications of canonical discriminant analysis in horticultural research. HortScience 29(10):1115-1119.

Figueroa-Solares, P., O. H. Jiménez, E. López de León and F. Anzueto, 2000. Influencia de la variedad y la altitud en las características organolépticas y físicas del café. 
pp. 493-497. In: L. Zamora and J. Echeverri (ed.), XIX Simposio Latinoamericano de Caficultura, Memoria, ICAFE, San José, Costa Rica.

Gobbi, J. A., 2000. Is biodiversity-friendly financially viable? An analysis of five different coffee production systems in western EI Salvador. Ecological Economics 33:267-281.

González-Arcos, F., 1996. Determinación de rendimientos en beneficio de café Coffea arabica, en diferentes altitudes de la región del Soconusco, Chiapas, Tesis Ingeniero Agrónomo. Fitotecnia-UACh, Chapingo, México. pp. 21-25.

Guadarrama, Z. C. and O. L. Trujillo, 2001. Calidad de café, variedades y fertilidad del suelo entre pequeños productores de Ixhuatlan del Café, Ver:: diagnóstico preliminar. Memorias XIV Reunión Científica-Tecnológica Forestal y Agropecuaria Veracruz, Ver. 25-26 Octubre. México.

Guyot, B., D. Gueule, J. C. Manez, J. J. Perriot, J. Giron, and L. Villain, 1996. Influence de l'altitude et de l'ombrage sur la qualite des cafes arabica. Plantations Recherche Developpement 3:272-283.

Haarer, A. E., 1980. Producción moderna de café. $4^{\mathrm{a}}$ impresión. México. 652 pp.

Himmelblau, D. M., 1997. Principios Básicos y Cálculos en Ingeniería Química. Pentrice Hall Latinoamericana, México. 728 pp.

Kamau, I. N., 1976. Effects of cultural practices on the quality of Kenya coffee Part I. Effects of Napier grass mulch and nitrogen fertilizers on the quality of arabica coffee in Kenya. Kenya Coffee 41:361-375.

Krzanowski, W. J., 1988. Principles of multivarate analysis. A user's perspective. Oxford, Clarendon. $380 \mathrm{pp}$.

Ky, C., L. Louarn, J. Dussert, S. Guyot, B. S. Hamon and M. Noirot, 2001. Caffeine, trigonelline, chologenic acids and sucrose diversity in wild Coffea arabica L. and C. canephora P. accessions. Food Chemestry 75:223-230.

Martín, M. J., P. F. González, A. G. Valdenebro and M. León-Camacho, 2001. Fatty acid profiles as discriminant parameters for coffee varieties differentiation. Talanta 54:291-297.

Montagnon, Ch. C., T. Ch. Leroy, A. Yapo and P. Charmetant, 2000. Genotype-location interactions for Coffea canephora yield in the Ivory Coast. Agronomie 20:101-109.

Muschler, R. G., 2000. Shade improves coffee quality in a sub-optimal zone of Costa Rica. pp. 109-123. In: L. Zamora and J. Echeverri (ed.), XIX Simposio Latinoamericano de Cafeticultura, Memoria, ICAFE, San José, Costa Rica.

Njoroge, J. M., 1998. Agronomic and processing factors affecting coffee quality. Outlook on Agriculture 27:163-166.

Puerta-Quintero, G. I., 2000a. Calidad en taza de algunas mezclas de variedades de café de la especie Coffea arabica L. Cenicafe 51:5-19.

Puerta-Quintero, G. I., 2000b. Influencia de los granos de café cosechados verdes en la calidad física y organoléptica de la bebida. Cenicafé 52:136-150.

Reyna, F., 1989. Evaluación de cinco variedades de café Coffea arabica Zona Río Arriba, El Paraiso. pp. 365-372. In: XII Simposio de Cafeticultura Latinoamericana, San Pedro Sula, Honduras.

SAS Institute, 1989. SAS/STAT User's Guide. Versión 6. 4th edition. Cary, NC.

Soto-Pinto, L., P. I. Castillo-Hernández and J. Caballero-Nieto, 2000. Shade effect on coffee production at northern Tzeltal zone of the state of Chiapas, Mexico. J. Agriculture Ecosystem Environment 80:61-69.

Steel, R. G. D. and J. H. Torrie, 1980. Principles and Procedures of Statistics: A Biometrical Approach. McGraw-Hill, New York. 633 pp.

Temesgen, G. and G. W. Michael, 1995. Determination of conversion ratios of fresh cherry to clean coffee on promising coffee cultivars at Gera. IAR Newsletter of Agricultural Research 10:9-12. 
van der Stegen, G. H. D., 2003. Enhancement of coffee quality by mould prevention. Food Control 14:245-249.

Villa, A., 1990. Cultivo del Café en México, Editorial La Fuente SA, México, pp 193-212.

Villaseñor, L. A., 1987. Cafeticultura Moderna en México. Editorial Futura, México. 467 pp. 